\title{
Secular and Liminal: Discovering Heterogeneity among Religious Nones
}

\section{Citation}

Lim, Chaeyoon, Carol Ann MacGregor, and Putnam, Robert D. 2010. Secular and Liminal: Discovering Heterogeneity among Religious Nones. Journal for the Scientific Study of Religion 49(4): 596-618.

\section{Published Version}

http://dx.doi.org/10.1111/j.1468-5906.2010.01533.x

\section{Permanent link}

http://nrs.harvard.edu/urn-3:HUL.InstRepos:5341589

\section{Terms of Use}

This article was downloaded from Harvard University's DASH repository, and is made available under the terms and conditions applicable to Other Posted Material, as set forth at http:// nrs.harvard.edu/urn-3:HUL.InstRepos:dash.current.terms-of-use\#LAA

\section{Share Your Story}

The Harvard community has made this article openly available.

Please share how this access benefits you. Submit a story.

Accessibility 
Title:

Secular and Liminal: Discovering Heterogeneity among Religious Nones

Chaeyoon Lim

Assistant Professor

Department of Sociology

University of Wisconsin-Madison

Carol Ann MacGregor

Ph. D. Candidate

Department of Sociology

Princeton University

Robert D. Putnam

Peter and Isabel Malkin Professor of Public Policy

John. F. Kennedy School of Government

Harvard University

Visiting Professor

University of Manchester

Word Count: 9,379 (including title, abstract, endnotes, and bibliography)

Acknowledgement and credits:

The authors thank Tom Sander, David Campbell, Shaylyn Garrett, James Montgomery, and the participants of the Politics, Culture and Society workshop at the University of WisconsinMadison and the Religion and Public Life workshop at Princeton University, for their helpful comments. We are grateful to the John T. Templeton Foundation for their generous support of the larger American Grace project, as well as their support of both waves of the Faith Matters survey.

Corresponding Author:

Chaeyoon Lim

Department of Sociology

University of Wisconsin-Madison

Mailing Address:

2446 Sewell Social Sciences Building

1180 Observatory Drive

Madison WI 53706

Phone/Fax: 608-263-5146/ 608-265-5389

E-mail: clim@ssc.wisc.edu 


\section{Introduction}

A long line of studies on religious switching and apostasy have shown that religious identity, for many people, is not a stable ascriptive characteristic. Retrospective data have illustrated that people often report belonging to a different religious tradition at the time of their interview rather than the tradition in which they were raised (Sherkat and Wilson 1995; Sherkat 1991; Smith and Sikkink 2003). Originally, there was a great interest in the implications of switching for the growth and decline of specific denominations, in particular, mainline Protestantism (Hoge, Johnson, and Luidens 1994; Roof 1999). Increasingly, the "switch” that is of most interest to scholars of religion is the movement towards identifying as a religious "none”. The increase in the number of Americans who choose "no religion" when asked about religious preference on national surveys (i.e., “nones”) has drawn much public and scholarly attention (Dougherty, Johnson, and Polson 2007; Hout and Fisher 2002; Meacham 2009; Stark 2008). Although major national surveys, including the General Social Survey (GSS), show a sharp increase of religious nones since 1990, there are some controversies surrounding the magnitude of the increase (Dougherty et al. 2007; Smith and Kim 2005). More importantly, it still remains largely unclear who religious nones are with respect to religiosity and why they claim no religious preference. Understanding the short-term stability of religious preference is also an important component of understanding the long-term growth of religious nones.

In an early study of Americans who claimed no religious preference, Vernon (1968:220) noted that those who do not identify with a political party are labeled independents (suggesting that the lack of political affiliation does not mean that one is apolitical or has no political convictions) while those who do not identify with a religious tradition are given a label (“nones”) that more accurately defines what they are not than what they are. Subsequent studies, using cross-sectional data, have advanced our understanding of some of the religious and demographic 
correlates of declaring no religious preference (Hadaway and Roof 1979; Hout and Fischer 2002; Baker and Smith 2008). Just as many independents are "leaners" or weak partisans rather than true neutrals, we know that not all nones are actually atheists or agnostics (Greer and Roof 1992; Hout and Fischer 2002; Kosmin and Keysar 2009; Stark 2008). ${ }^{1}$ However, a lack of appropriate data has prevented us from examining whether those with no religious preference are neutral independents or might more accurately be considered leaners—-with some ties to one religious preference or another.

Using a new panel data set on American religiosity, we take a more dynamic approach to the study of nones and look at the short-term stability of this self-identification among the same people interviewed twice over a two-year period. We introduce the idea of liminality as a framework for understanding the short-term instability of religious preferences. Just as many political independents are actually leaners, we argue that many religious nones are actually liminal somethings, who still hold a weak sense of attachment to a religious tradition and thus may identify with the tradition sometimes, if not always. Although our notion of liminality can be extended to all religious traditions, we pay special attention to nones because of their growing importance in the American religious landscape. Disaggregating those who identify themselves as nones at least once in panel survey is an important first step in understanding who religious nones are and the implications of their growing presence for the religious landscape of America. A rise in the number of atheists is qualitatively different from a rise in the number of unchurched believers, and a rise in the number of those who consistently identify with no religious preference is qualitatively different from a rise in the number of those with a more liminal identification. 
The paper proceeds as follows: first, we describe how liminality has been used in the past, outline how we use the term, and suggest its overall utility for the study of religious identity. Second, we survey the literature on religious nones and outline how decomposing this group into secular and liminal improves our understanding of this important segment of the population. Third, using data from the Faith Matters (FM) Survey, we describe the stability of religious preferences in panel data. We test the robustness of our findings by replicating them with the American National Elections Study (ANES) and the General Social Survey (GSS). We try to disentangle the instability due to actual religious changes from the unreliability of a measure that does not accompany changes in religious identity. Then we compare the religious characteristics of liminal nones, who identify themselves as nones at one time but choose a different preference at another time, with the stable nones, who consistently identify with the 'no religion' category, as well as with those who consistently identify with a religious group (stable affiliates). In addition, we compare the three groups in their socio-demographic profiles and their views on some of the key social and political issues to understand what factors are associated with liminal religious identities. Finally, we conclude by discussing the broader implications of our findings and suggesting directions for future research.

\section{Liminality and the Instability of Religious Preferences}

Liminality, as discussed by the cultural anthropologist Victor Turner, is the middle stage in three stage ritual process in which liminars (or ritual subjects) redefine their identity under conditions that have "few or none of the attributes of the past or coming state" (Turner 1969:94, 1979; Turner and Turner 1978). They are, as Turner notes, “betwixt and between.” Turner’s conception of liminality has been applied by sociologists of religion to phenomena as diverse as African American Pentecostalism, the Promise Keepers, Glossolalia, and Spiritualist Healing 
(Bobby 1991; Bartkowski 2000; Hutch 1980; Fishman 1980). We step back from this more narrow definition of liminality as it pertains to ritual and instead focus on the more general notion of being betwixt and between. We also move away from the notion of liminality as a trajectory with religious participation and secularism as poles. ${ }^{2}$ Liminars, in our view, are individuals betwixt and between the religious and the secular but they are not necessarily on the path to being one or the other. They stand halfway in and halfway out of a certain religious identity. It is possible, in our conception, that liminars have willfully chosen their particular combination of beliefs and practices and are content to remain in what we call a liminal status throughout their lives.

Because of the liminal nature of their religious identity, they may identify with certain religious group at one point, but claim no religious preference at another, although their overall religious involvements change little. Liminars differ from apostates or switchers, who actually experience changes in their religious beliefs and behaviors, not just in their expressed religious identity (Brinkerhoff and Mackie 1993). In a sense, they are analogous to what Brody (1986) referred to as 'gray' in respect to the stability of social and political attitudes. Building on Converse's classic attitude/non-attitude model, he suggests that the instability of response in panel survey may reflect, not the lack of attitude towards a certain issue, but a relatively lower level of issue crystallization. Because liminars' levels of preference crystallization are in the 'gray range,' their (manifested) religious identity is a situational, rather than a stable, trait, that has the potential to vary from one context to the next (Markus and Kunda 1986; Stryker and Serpe 1994).

The notion that religious identities can be ambiguous is certainly not novel. Scholars of religion, in examinations that span denominations, generations, and geographical contexts, have 
developed labels including "the spiritual but not religious”, "believing without belonging” “religious seekers”, “unchurched believers”, “tinkerers,” “fuzzy fidelity,” and “religious privatists" that all reflect the reality that the true range of religious identities is not captured by the sets of religious categories that are often used in survey research on religion (Bellah et al 1985; Davie 1994; Fuller 2001; Greer and Roof 1992; Roof 1993; Voas 2009; Wuthnow 2007). We suggest, however, that the notion of liminality offers a more useful conceptual framework to understand the ambiguous status of religious identity for a substantial segment of Americans who claim no religious preference. Compared to the labels like "unchurched believers" or "religious privatists," which appears to assume a certain stable religious predisposition, the notion of liminality highlights the potential for a situational, indeterminate or porous type of religious identity, ${ }^{3}$ and thus will help us better understand the diversity within religious nones. ${ }^{4}$ We turn now to highlighting what is known about religious nones.

\section{Religious Nones: Secular or Liminal?}

Several studies have examined who religious nones are, why their number is on the rise, and what their growing presence means for the religious landscape in America. In one of the earliest studies, Vernon (1968) noticed that despite not identifying with any particular religious group, a good percentage of nones have some belief in God or a higher power, and report having had religious experiences. Based on the findings, he called for further scholarly investigation of religious nones, which he called “a neglected category.” Subsequent studies have confirmed Vernon's findings that nones are an internally diverse group with respect to religious beliefs and behaviors and that many of them hold some beliefs in God or a higher power (e.g., Hout and Fisher 2002; Stark 2008). 
However, scholars disagree on why people claim no religious preference and how we should characterize their religious identities. As a result, there is little consensus on what the rise of nones means for religion in America. Some view many of the nones as religious believers fleeing organized religion, and argue that they should be considered not as evidence of increasing secularization or the decline of religion in general, but as an indication of a transformed but still vital religiosity in America (Greer and Roof 1992; Roof 1993, 1999; Cimino and Lattin 1998; Hout and Fischer 2002). Using a typology developed by Tamney, Powell, and Johnson (1989), those that claim no religious preference could be either "structural nones" who are critical of the social role played by organized religions and religious leaders, or “cultural nones” who disagree with traditional religious beliefs or values. Others, however, suggest that nones are, in fact, seculars (or at least are on their way to becoming secular), and view the increase in their number as an indication of the secularization in America (Glenn 1987; Bruce 2002; Marwell and Demerath III 2003).

To advance this debate, as Baker and Smith (2008) propose, we need to focus on the diversity within nones and examine the different groups that may comprise the category. In particular, we need to take a close look at who they are, what exactly they believe, and how consistent their religious preferences are over time. In this paper, we shed light on a new dimension of the diversity by examining the stability of the 'no religion' preference in panel data. Although previous studies disagree on why people claim no religious preference, most seem to assume that the 'no religion' preference represents a stable status of religious selfconceptualization, and that the boundary between religious nones and religious affiliates is clear. However, there are some indications that the boundary may be more porous and fuzzier than is assumed. Hadaway and Roof (1979), for example, observed that two thirds of the 1973-1977 
General Social Survey respondents who had been raised as nones identified with a religious group as adults. Using longitudinal data in the U.S. and abroad, a few studies have also reported instability of religious identities, especially for those who chose the 'no religion' preference (Voas 2009; Wilson and Sherkat 1994). Wilson and Sherkat (1994) have shown that inconsistent religious identities often reflect the "life cycle effects" due to key life course events such as family formation. To be sure, the ‘no religion’ has become a more stable religious selfidentification in recent years, especially among younger generations (Hout and Fischer 2002). But even in the latest General Social Survey, more than $40 \%$ of the respondents who had been raised as nones reported something else as their current religious preferences.

$<$ Insert Figure 1 approximately here $>$

Moreover, survey procedures that measure religious preference seem to have a substantial effect on whether people claim no religious preference or not. Figure 1 compares the trends in the percentage of religious nones across four major national surveys over the last several decades. It shows that the percentage of nones in a given year varies significantly across the surveys, especially since 1990. Gallup survey, which does not explicitly suggest 'no religion’ to respondents as a possible answer, reports a significantly lower percentage of nones than other surveys do (Winseman and Min 2005; Hout and Fisher 2002). On the other hand, the ANES, which employs a rather complex procedure to measure religious preference, reports a highest percentage. ${ }^{5}$ More importantly, these surveys disagree about the timing of the growth of religious nones. For example, the Gallup indicates that the percentage of nones grew in 1970s and 1980s, but remained relatively flat in 1990s, whereas the GSS shows little change until the rapid rise in 1990s. These discrepancies between the surveys imply that for many respondents, the choice between 'no religion' and conventional religious groups may not be clear-cut, and 
they may have some sense of attachment to a religious tradition. In the analysis that follows we examine the issue of the boundary between nones and affiliates by focusing on the stability of no religious preference in two panel surveys.

\section{Data and Measurement}

To examine the stability of the nones, we use panel data collected in 2006 and 2007 as part of the Faith Matters (FM) Study, a nationwide study that focuses on religious life of American adults. In 2006, a representative sample of American adults over 18 years old $(\mathrm{N}=3,108)$ was interviewed by a commercial research company. ${ }^{6}$ The response rate was 69\% (based on the formula 5 of the AAPOR). In comparison, the response rate for the 2006 GSS, based on the same formula, is $71 \%{ }^{7}$ A year later, these respondents were contacted for the second wave of the study. More than sixty percent (61.6\%) of the original respondents were successfully re-interviewed. ${ }^{8}$

Because the two waves are only a year apart, the FM data offer a valuable opportunity to study the short-term stability of religious preferences. Although it is a difficult task to distinguish the instability that is due to actual switching of religious preference from the fluctuation due to vague instruments or a low level of preference crystallization with only two waves of data (Alwin 2007; Green, Palmquist, and Schicker 2002), the FM data contain identical measures of religious beliefs, attitudes, and behaviors in both waves, thus allowing us to examine whether the change in religious preference matches self-reported changes in various aspects of religiosity. In addition, the 2007 survey directly asked respondents whether they experienced any change in religious belief or behavior in the past year and also in the past five years. We use these questions along with other measures of religiosity to examine whether inconsistent reports of preference reflect actual changes in religious preferences. 
We also use the American National Election Study and the General Social Survey to replicate the key findings from the FM data. The stability of religious preference in a panel survey could be influenced by many factors, including the exact wording of the question, the contexts in which the preference question is asked, the method of interview, and sample attrition. Therefore, it is important to examine whether the findings about the stability of religious preference can be replicated with different datasets. We use the 1992-1994-1996 ANES and 2006-2008 panel data to examine whether our core findings can be replicated.

The key variable of interest in this study is religious preference. In the FM survey, respondents were asked: "What is your religious preference? Is it Protestant, Catholic, another type of Christian, Jewish, some other religion, or nothing in particular?” This question is slightly different from major national surveys including the GSS, which include 'no religion' instead of 'nothing in particular' as one of the suggested responses. The GSS also does not suggest 'another type of Christian' as a possible answer. Despite these differences, the two surveys produced comparable results: in the 2006 GSS, 15.9\% chose 'no religion,' whereas $16.5 \%$ in the 2006 FM chose 'nothing in particular.' The ANES panel data not only was conducted more than a decade before the FM and the GSS panel surveys, but also used a very different procedure to measure religious affiliation (see Appendix A for more details). Therefore, if we can replicate the key findings with the ANES data, it would indicate that the findings on the stability of religious preference are robust to a specific procedure to measure religious affiliation.

Results

$<$ Insert Table 1 approximately here>

Our first task is to examine how stable no religious preference is over time in the FM dataset. In Table 1, we cross-tabulated the religious preferences from the two waves of the FM 
survey. The diagonal cells show the percentage of respondents who reported a consistent religious preference in both years. Fewer than $70 \%$ of the respondents who chose 'nothing in particular' in the first wave reported the same preference in $2007 .{ }^{9}$ This is substantially lower than the percentages for major religious groups such as Protestant and Catholic, in which 86\% and $92 \%$ respectively gave a consistent answer in the two surveys. The two residual categories'another type of Christian' and 'some other religion'—are even less stable than 'nothing in particular.' The instability of these two categories appears to be related to a fuzzy boundary in and around Protestantism. Most of the respondents who switched out of the 'another type of Christian tradition' category chose either Protestant or 'some other religion' in 2007. We looked at their denominations and found that a majority of these 'switchers' gave the same denomination in the two surveys. About 55\% of them belonged to either evangelical or black Protestant denominations, and an additional $12 \%$ were Mormons. Similarly, about a half of the respondents who switched out of "some other religion" belonged to those three religious groups. In other words, a strong denominational identity that does not map onto these aggregate categorizations in certain Christian groups, and not substantial volatility in smaller religious groups, like Buddhists and Muslims, seems to account for the low stability of these two residual categories.

Because more than 30\% of the respondents in the 'nothing in particular' category in 2006 switched to other preferences in 2007, one may expect the percentage of nones in the second wave to be significantly lower than the percentage in the first wave. However, the percentage of nones remains similar in the two surveys $-15.4 \%$ in 2006 and $14.9 \%$ in $2007 .{ }^{10}$ This is because some respondents—a similar number to those who moved out of the 'nothing in particular' category — moved into the category in 2007. In other words, although approximately the same 
percentage of respondents chose 'nothing in particular' in both surveys, they are not exactly the same respondents. As a result, there are three different types of nones in the FM data with respect to the stability of religious identity: 1) those who consistently chose 'nothing in particular' in both surveys; 2) those who switched from 'nothing in particular' to other preferences; and 3) those who switched from other preferences to 'nothing in particular.' Table 2 shows these different types of nones as a percentage of the total panel sample. Among the respondents who participated in both waves of the survey, only $9.6 \%$ are stable nones who consistently chose 'nothing in particular', whereas 9.4\% are unstable nones—-liminal nones— who chose 'nothing in particular' in only one of the two waves. ${ }^{11}$

$<$ Insert Table 2 approximately here>

Table 2 also shows that the instability of no religious preference is not limited to the FM data but can be found in the ANES and GSS panel data as well. As mentioned earlier, the 19921996 ANES used a very different procedure to measure religious preference from the FM survey, and therefore the percentage of nones in the two surveys is not directly comparable. ${ }^{12}$ The response categories suggested to the respondents in the GSS were also slightly different from those in the FM survey. In addition, the intervals between the waves in the ANES and the GSS are two years—-four years for a subset of the ANES respondents—-which are substantially longer than that of the FM survey. As a result, the respondents in these surveys have a higher chance to experience actual changes in their religious preferences and thus we may expect a lower level of response stability in these surveys than in the FM survey.

Despite these differences, we found that the instability of no religious preference is similar across the three panel datasets. In the GSS panel data, $10.8 \%$ of the respondents consistently identified with "no religion" in both waves, whereas $10.4 \%$ did so in only one of the 
two waves. ${ }^{13}$ Similarly, the ANES panel classified $8 \%$ of the respondents as stable nones and 9.7\% as unstable nones. In short, the proportion of unstable nones was very similar in all three surveys and it was comparable to that of stable nones in each survey. These findings suggest that the instability of religious nones is probably not due to the procedure or instrument used to measure religious preference in the FM survey. More importantly, the fact that a similar level of instability is found regardless of the length of interval seems to suggest that the instability observed in these datasets is unlikely to reflect actual changes in religious preference. If the instability is attributable largely to the true conversion of religious preference, the instability would be probably higher when the interval between the waves is longer because respondents have more time to experience religious changes. Table 2 shows that this is not the case.

To take a closer look at whether the instability of the 'no religion' preference reflect actual changes in religious identity, we examine respondents’ self-reports on religious changes they experienced between 2006 and 2007. In 2007, all FM respondents were asked whether they had experienced any change in their religious beliefs or practices over the last twelve months. When they said that they had experienced changes, interviewers then asked whether their religiosity increased or decreased in the past year. In addition, the FM survey-in both 2006 and 2007_asked whether the respondent's religious service attendance changed in the past five years, which provides some insight into the long-term stability of respondent's religiosity. Table 3 and 4 show the results for these two variables respectively. ${ }^{14}$

$<$ Insert Table 3 and 4 approximately here $>$

Overall, less than $10 \%$ of the total panel respondents reported any change in their religious beliefs or behaviors in the past year. Of the respondents who switched from 'nothing in particular' to something else, only 15\% said that they had experienced any change, and an even 
smaller percentage (7.6\%) said that they had become more religious between 2006 and 2007. Among those who switched into the 'nothing in particular' category from other religious preferences, only $8 \%$ reported any kind of religious change, and $2 \%$ said that they had become less religious in 2007 than in 2006. In short, the vast majority of the respondents who switched in and out of the 'nothing in particular' category reported no change in their religious beliefs or behaviors. Even when they did report changes, the direction of the reported change often contradicted the change in their reported preferences. In addition, Chi-squared test suggests that there is no significant association between the stability of religious preference and self-reported change in religious belief or practice.

More respondents reported changes in religious service attendance in the past five years than did so for the past year. Still, more than $58 \%$ of the liminal nones said that their religious service attendance had remained about the same in the past five years. Their responses are significantly less stable than the stable affiliates' and especially than the stable nones', but adjusted residuals suggest that the difference is relatively moderate. Moreover, the direction of the change among those who reported a change is not necessarily consistent with that of religious preference. For example, 19\% of the unstable nones who switched from 'nothing in particular' to something else said that their religious attendance had declined in the past five years. In short, a majority of the unstable nones do not appear to have experienced significant changes in their religious beliefs and behaviors, not only in the short run, but also in the mid-term.

$<$ Insert Table 5 approximately here $>$

To further examine religious changes that the unstable nones may have experienced, we compare various indicators of religious beliefs and behaviors between when they chose 'nothing in particular' and when they reported something else (Table 5). For comparison, we also 
presented the percentages of stable affiliates and stable nones who gave a consistent response in the two surveys. To be sure, these indicators themselves could fluctuate due to measurement errors rather than actual changes in religious beliefs or behaviors. In fact, because most of these variables were measured on interval scales, there is a higher chance of instability due to random measurement errors for these variables than for religious preference. Therefore, self-reported changes in one or a few of these indictors—even a substantial change—should not be viewed as a reliable indicator of actual changes in religiosity. However, if someone who reported different religious preferences in the two waves also reported a consistent change across multiple measures of religiosity, it may be considered strong evidence that the instability of religious preferences reflect actual changes in religious identities.

In many measures we examined in Table 5, the liminal nones gave significantly less consistent answers when compared to the stable affiliates and the stable nones. This relatively high level of inconsistency may be viewed as evidence that the changes in their religious preferences are 'real.' However, in most of these measures, about a half or more of the liminal nones gave an exactly same answer in the two surveys. Moreover, even among those who gave inconsistent answers, less than $30 \%$ of the unstable nones reported a higher level of religiosity when they identified with one of religions than they did when they chose 'nothing in particular.' A substantial percentage of the unstable nones even reported a higher level of religiosity when they chose 'nothing in particular.'

A relatively large percentage reported a higher level of religious service attendance and prayer when they chose something other than 'nothing in particular,' but this may well be because these variables were measured with a finer scale than the other measures of religiosity. The finer the scale is, the less likely it is that respondents will give the exact same answer over 
time (Green et al. 2002). In fact, most of the changes in these variables—or in any other measure of religiosity, for that matter-were between adjacent categories, such as between 'less than once a year' and 'about once or twice a year.' Only about 3\% of all unstable nones, for example, changed from 'never' or 'less than once a year' to 'every week' or 'more than once a week.' Furthermore, we found that only a small percentage of respondents reported a higher level of religiosity consistently across multiple measures when they chose preferences other than 'nothing in particular.' For example, only four percent of the liminal nones reported a higher level of religiosity in all of the three key measures of religiosity_religious importance in daily lives and to self-identity, and religious service attendance-when they identified with religious categories other than 'nothing in particular.'

In summary, the evidence in the three proceeding tables suggests that the instability of the 'nothing in particular' preference in the FM survey does not reflect substantial changes in religious belief or behaviors for most of the unstable nones. A small subset of them may have experienced significant changes between the two surveys, and thus the changes in their reported preferences may reflect actual switching of religious self-identity. However, we estimate that the true switchers account for only a small percentage_-probably much less than $10 \%$ at best—of the unstable nones.

If the religious behaviors and beliefs of most of the unstable nones did not change significantly between the two surveys or even in a relatively long-term, which preference better represents their true religious identities? One way to answer this question would be to compare the unstable nones to the stable nones and the stable affiliates with respect to their religious beliefs and behaviors. If the unstable nones are similar to the stable nones, we may infer that the 'nothing in particular' category describes their religious identities better than any religious group 
they identified with in the other survey. To make the comparison simpler, we first summarized the measures of religiosity we examined in Table 5 into three factor-score indices: importance of religion, religious practice, and religious belief. In addition, we created a summary index of overall religiosity based on attendance, importance of religion in daily life, importance of religion to the sense of self, and belief in God. Figure 2 shows the means and the $95 \%$ confidence intervals of the four indices for the three groups. For the unstable nones, we presented the means and the confidence intervals separately when they reported 'nothing in particular' and when they reported something else.

$<$ Insert Figure 2 approximately here>

Looking at all four measures of religiosity, the unstable nones are significantly different from the other two groups. On average, they are more religious than the stable nones, even when they reported the 'nothing in particular' preference. They are, however, significantly less religious than the stable affiliates even when they chose something other than 'nothing in particular.' Figure 2 also shows that whether they claimed no religious preference or something else, there is no significant difference in any of the four indices of religiosity. In other words, regardless of their reported preferences, the unstable nones are distinctive from both the stable nones and the stable affiliates in various dimensions of religiosity.

The comparison presented in Figure 2 is informative as it shows the location of the unstable nones as a group relative to the other two groups. However, it masks the heterogeneity, not only within the unstable nones, but also within the other two groups. As we have already seen, the unstable nones include both highly religious and highly secular people. Similarly, not all of the stable affiliates are highly religious in their beliefs and behaviors. To take these 
heterogeneities into account, Figure 3 compares the distribution of the summary religiosity index in the three groups.

$<$ Insert Figure 3 approximately here $>$

Figure 3 shows that the stable nones are a relatively homogeneous group of people, most of whom are concentrated in the lowest level of religiosity. Although many of them are not atheist or agnostic, ${ }^{15}$ almost $60 \%$ of them never attend religious service and $83 \%$ of them said that religion is not important to their self-identities. In other words, the stable nones seem to be solidly secular in the sense that they are not concerned with religious or spiritual matters and do not practice religion publicly or privately on a regular basis. In comparison, the unstable nones are an internally heterogeneous group. Some of them belong to the least religious group, whereas others—although a minority—are highly religious. In addition, there is a substantial overlap between the unstable nones and the stable affiliates, as many of the latter are not very religious.

$<$ Insert Figure 4 approximately here>

While these patterns offer a more complex picture of the unstable nones than the one presented in Figure 2, Figure 3 still shows the in-between position of a majority of the unstable nones. They are only moderately religious at best, neither highly religious nor completely secular. "Unchurched believers," a label often suggested for nones in the literature, does not seem to correctly characterize them either. Many of the unstable nones (41\%) claim that they attend religious services at least several times a year, and about a third claim to have a congregation they belong to. More than $80 \%$ of them confess some beliefs in God, but at the same time, more than two thirds say that religion is only 'somewhat important' or 'not important' to their self-identities. Most of them do not seem to be particularly spiritual, as only $20 \%$ said that they were "very spiritual." In other words, "spiritual seeker" does not seem to fit 
the religious profile of the unstable nones well either. Instead, liminality seems to characterize the religious beliefs and practices of this group. They are located at the margin of their religions, which they feel some attachment to and get involved in occasionally, but their connections are not strong enough to make them consistently identify with the religion or to consistently claim no religious preference.

What are the religious traditions these liminal nones identified with when they did not choose the 'nothing in particular' category? Is the liminality more common in certain religious traditions than in others? To answer this question, we classified the respondents into nine different religious traditions based on their religious preferences and denominations, and presented the percentage of liminal nones among the respondents who identified with each tradition in at least one of the two surveys, along with the 95\% confidence intervals (Figure 4). Liminal nones are most commonly found in the two 'other' categories— 'other non-Christian tradition,' the catchall category for non-Judeo-Christian traditions, and 'other Protestant/Christian traditions. ${ }^{16}$ While not as high as these two residual categories, most traditions have a substantial number of liminal nones of their own. In particular, 8 to $11 \%$ of the respondents who identified with one of the three Protestant traditions, including evangelical and Black Protestants, chose 'nothing in particular' in one of the two waves. In other words, liminality is not limited to a certain religious tradition, but found in all major religious traditions in the U.S. As such, when scholars are working with a single survey, they should be aware that roughly $10 \%$ of the people who claim that they are "something" won't be there a year from now, even without any real "conversion." In other words, each of the major religious traditions seems to be surrounded by a penumbra of very loosely attached "liminal” affiliates.

$<$ Insert Table 6 approximately here $>$ 
To get further insights on who the liminal nones are, we estimate a series of multinomial logistic regressions that predict liminality with socio-demographic, religious, and sociopolitical factors. The baseline category in the four models presented in Table 6 is the liminal nones, thus each coefficient indicates the difference between the liminal nones and the stable affiliates or the stable nones. With respect to socio-demographic factors, the results suggest that the liminal nones are similar to the stable nones in almost all variables we observed, and different from the stable affiliates in age and marital status. On average, both the liminal and the stable nones are younger and more likely to be single than the stable affiliates are. In other words, a similar set of factors separate all nones from the stable affiliates, whereas there is little difference between the stable and liminal nones in most socio-demographic factors.

One factor that deserves some attention is age. Because religious identity could still be emerging in early adulthood and also because religious involvement tends to be lower for young adults due to the life cycle effect (Wilson and Sherkat 1994; Wuthnow 2007), we may expect the liminality to be more common among young respondents. This proposition, however, is not supported by the FM data as the liminal nones are actually slightly older than the stable nones, although the difference is not statistically significant. The breakdown by age group shows that those in the youngest group are actually more likely to be stable nones than liminal nones, whereas in all other age groups, the percentages of the stable and liminal nones are comparable (see Appendix C). ${ }^{17}$ In short, liminality does not appear to be a temporary phase of religious disengagement due to life-cycle effects.

Religious upbringing also separates the stable and the liminal nones from the stable affiliates as both groups report that they attended religious services less frequently as children and are more likely to have parents who are religious nones (Model 2). But religious upbringing 
does not explain the gap in religiosity between the liminal and the stable nones. The two groups, however, diverge in the other two religious background variables-i.e., religious preferences of spouse and children. Compared to the liminal nones, the stable nones are significantly more likely to have spouses and children who also are nones themselves (Model 2 and 3). ${ }^{18}$ One possibility is that the stable nones, who tend to be less religious than the liminal, selectively married someone who was not religious and raised their children secularly. Another possibility, however, is that the religious family members keep the liminal nones involved in religion, if only weakly. In other words, having religious family members could be both the cause and the outcome of the liminal religious identity.

Finally, Model 4 compares the views on some social issues and political orientations of the three groups to see whether the liminal nones have different political and social outlooks (not just religious outlooks), from the stable nones and the stable affiliates. The results show that they do. The liminal nones are significantly more liberal than the stable affiliates, but more conservative than the stable nones. They are also in-between in their attitudes towards sensitive issues, such as abortion and gay marriage although the differences in these issues are statistically insignificant when political orientation is controlled for. In other words, the liminal nones are a distinctive group from the other two, not only in terms of their religious beliefs or practices, but also in terms of their social and political views.

\section{Discussion}

In this study, we have tried to advance our understanding of religious nones, the fastest growing religious category in America, by examining the stability of their religious identity with new panel data. Many studies have observed that the number of nones in national surveys has increased rapidly, but disagreed on why they claim the 'no religion' preference and what their 
increasing number means for religion in America. We tried to shed light on this debate by asking how stable the 'no religion’ preference is as a category for religious self-identification. Using data from three separate panel data sets, we found that religious nones comprise two distinct groups; one whose members consistently claim no religious preference and the other whose members do so in one wave but choose something else at another time, despite that they did not appear to have experienced significant religious changes between the waves. The former, which accounts for about $10 \%$ of the respondents in all three surveys we examined, may be referred to as seculars, as most of them have little connection to religious belief or practice. Some of them do confess belief in God or higher power, but they do not practice religion on a regular basis, nor consider religion as an important part of their daily lives or to their sense of self. In contrast, the people who fail to identity with the 'no religion' preference consistently-i.e., the liminal nones — are, on average, significantly more religious than the stable nones in all measures of religiosity we examined. On the same measures, however, they are significantly less religious than the people who consistently identify with a religious group. Though they have some attachments to their religious groups, the attachments are not salient enough to make them identify with the group consistently. In other words, their inconsistent reports on religious preference in panel surveys appear to reflect a liminal status of religious identity rather than volatility in their religious beliefs or behaviors. We estimate that this group, which we labeled as the liminal nones, accounts for another 9-10\% of the FM and GSS respondents. In some sense stable or secular nones really mean it, but the liminal nones are, in effect, signaling a weaker religious affiliation, not the complete absence of religiosity. The problem, of course, is that in any single survey the two types of nones are virtually impossible to distinguish with standard questions about religious affiliation 
The discovery of these two distinct subsets of Americans with no religious preferencesecular and liminal—sheds new light on the debates surrounding religious nones. The studies that have suggested that religious nones are unchurched believers — who are religious but reject organized religion, tend to focus on the distinction between believers and non-believers among religious nones. Observing that a majority of religious nones confess some belief in God or a higher power, they conclude that most religious nones reject organized religions, not religion itself. Along the same lines, some argue that those unchurched believers are religious individualist or spiritual seekers who pursue their religious passions privately outside religious institutions. Our findings do not offer much support for this claim. The stable nones, who consistently select no religious preference, are secular on all measures of religiosity we examined. Although many of them are not atheist or agnostic, there is no evidence that they are privately religious or spiritual.

The liminal nones also differ significantly from the people who consistently identify with one of organized religions, not only in their church attendance but also in all other aspects of religiosity, including religious beliefs and the salience of religion in life. There is little evidence that the liminals are particularly spiritual, either. In other words, we found little indication that they are active ‘seekers’ who pursue their religious passions privately outside religious institutions. In fact, they are not completely 'unchurched' either. Many of them claim that they have congregations they regularly go to when they attend religious service. More importantly, they do identify with one of the organized religions in one of the two waves.

While our findings on the characteristics of liminal nones seem to lend more support to the secularization thesis than to the 'religious privatism' or 'spiritual seekerism' hypotheses, they also pose some challenges for it as well. It is true that the liminals are significantly less religious 
than the people with a stable religious affiliation. In fact, a majority of them are found on the lower half on the overall religiosity scale. They are also statistically indistinguishable from the stable nones in various socio-demographic factors and religious backgrounds. In other words, a similar set of factors separate both the liminal nones and the stable nones from the stable affiliates. Therefore, it seems to be a reasonable speculation that their liminal religious identity may be fading out in the long run. However, some of our findings cast doubt on this speculation. A majority of the liminal nones claim their religious service attendance did not change in the past five years. We also found little evidence that their religiosity declined significantly between the two surveys that were conducted a year apart. In other words, despite the instability in their reported religious preferences, their marginal involvement in religion appears to be enduring. When they do experience religious changes, they do not necessarily head towards secularism. In fact, the evidence from earlier generations suggests that many unstable nones or even stable nones reclaim their religious identities and get involved in religion later in their lives (Hadaway and Roof 1979; Wilson and Sherkat 1994). Although we do not know whether this life-cycle pattern would repeat in younger generations, our findings suggest that religious changes of the liminal could happen in both directions.

More importantly, the liminal nones are more likely to be married to someone with religion and to have children who also have religion than the stable nones are. Having close family members who are religious could buttress their connections to religion and thus make it more durable. More importantly, compared to the stable nones, the liminal nones are much less likely to pass their lack of affiliation on to their children. Only a third of the liminal nones with children reported that their children had no religious preference, whereas two thirds of the stable 
nones did. In other words, their liminal religious identities may not necessarily lead to further secularization in the next generation.

Our findings about liminal nones have implications for survey research about religion, especially on how to measure religious preference in surveys. As mentioned earlier, different survey procedures lead to significantly different estimates of religious nones, ranging from $11 \%$ to almost $20 \%$ in recent years. Our findings suggest that the presence of liminal nones may account for this discrepancy. Because of their limited attachment to religion, liminal nones may or may not identify with a religious group depending on how the question is framed. The national surveys with lower estimates of religious nones often do not suggest 'no religion' explicitly as a possible answer (e.g., the Gallup Poll) or ask follow-up questions to detect even a marginal religious attachment, and as a result, may classify many liminal nones as religious affiliates. In contrast, the surveys that explicitly suggest ‘no religion' as a possible answer probably categorize many of the liminal nones simply as nones. In other words, the lower estimates of "nones" in some recent surveys probably reflect the share of stable nones (or pure seculars) among American adults, whereas the higher estimates in other surveys probably include both stable nones and liminal nones.

Future survey research will need to design a procedure that could capture both stable and liminal nones, but at the same time draw a distinction between the two groups. The new procedure needs to consider that religious affiliation is a "fuzzy-set” rather than a "crisp set" (Ragin 2000). In crisp set, only two mutually exclusive states are allowed: member and nonmember. As our analyses showed, however, religious affiliation in reality is much fuzzier. Some may be half in and half out, while others are more in than out or more out than in. But because of the way religious preference question is asked in conventional surveys and also because how 
religious affiliation is often conceptualized as a crisp set, "shades of gray (fuzziness) are constrained to be either black or white" (Ragin 2000: 154), forcing those in the range of gray to bounce back and force between affiliation and non-affiliation. One possible solution is to model after the procedure often used to identify partisan leaners (political independent who lean towards one of the parties) and ask the respondents with no religious preference a follow-up question on whether they have any sense of attachment to a religious tradition or which religious traditions they were raised in. To be sure, even with this improved procedure to capture different shades of affiliation, the liminal nones' self-reported preferences are likely to bounce around, because of the lower level of preference crystallization. As shown in Table 5, even when religiosity was measured with fine categories including equivocal options, the liminal nones are more likely to respond inconsistently than the stable nones or the stable affiliates do. Still, the new procedure will help us to better capture the heterogeneity within religious nones.

Our findings about liminal religious identity also call for more panel studies that track individual religious preferences in multiple waves of surveys and over a period longer than one or two years. Panel surveys often include religious preference only in the initial wave under the assumption that religious preference remains stable over time. Our findings suggest that this is not the case, especially for those we have traditionally called "nones," but also for the other religious categories. Panel data with more than two waves over a long period would be essential to study the stability of religious preference and the direction of religious changes, both in the short-term and the long-term.

The improved procedure to measure religious affiliation and well-designed panel surveys will help us to understand whether the growth in the number of Americans with no religious preference reflects a growth of the secular or a growth of the liminal. As shown in Figure 1, 
different national surveys disagree not only on the current size of the population of religious nones, but also when the growth of the category took place. Given how the Gallup survey and the GSS measure religious preference, the patterns in Figure 1 seem to suggest that the post-1990 growth may be attributable to liminal nones rather than to stable nones. However, we also found that the youngest cohort in the FM survey is significantly more likely to be a stable none rather than a liminal none, indicating that the recent growth may be actually the rise of stable nones.

The distinction between these two scenarios would be critical for understanding why more Americans claim no religious preference in recent years and what implications the rise of religious nones has for American religion. A growth in the number of liminal nones who remain marginally religious because of the buttressing effect of religious family members would alter American religion in a much different way than a growth in the number of stable-nones who leave religion permanently. Just as political analysts must ascertain in which direction political independents are likely to lean in order to predict the outcome of an election, scholars of American religion need additional information if they are to predict whether America is charting a path similar to Europe, where those that are neither very religious nor specifically non-religious comprise half the national population (Voas 2009), or if it will continue to be one of the most religious nations in the world.

\footnotetext{
${ }^{1}$ Sherkat (2008), for example, shows that 33\% of nones are either atheists or agnostic. In the FM data, 16.6\% said that they did not believe in God's existence, and 22\% said that they were either "not at all sure" or "not quite sure" whether God exists.

${ }^{2}$ Rottenburg (2000), who used liminality to study a bar on the border between Poland and Germany right after the fall of the Berlin wall, noted that a liminal status may not be necessarily of limited duration. Instead, this state of limbo could be a new, distinctive status that could last long or even permanent. See also Czarniawska and Mazza (2003).

${ }^{3}$ Recently Chaves (2010) has pointed out that sociologists of religion often fall into the "religious congruence fallacy," which presumes that "religious beliefs and values indicate stable and chronically accessible disposition in people" (2). He suggests that we should focus on the fragmented and situational nature of religious beliefs and practices rather than adhering to this unwarranted assumption of congruence. With liminality, we attempt to emphasize the incongruence in religious identity.
} 
${ }^{4}$ Our notion of liminality as it applies to religious nones resembles most closely Voas'(2009) conception of “fuzzy fidelity". However, we suggest that unlike fuzzy fidelity the concept of liminality might usefully be applied to other religious groups.

${ }^{5}$ The American National Election Study changed its procedure to measure religious preference significantly in 1990. As a result, the trends before and after 1990 are not directly comparable. In Figure 1, we used different types of line and symbol to indicate this change.

${ }^{6}$ The study was introduced to the respondents as a survey on "some current events.” The interview began with questions that are not directly related to religion.

${ }^{7}$ The National Opinion Research Center 2010. Please see the American Association for Public Opinion Research (2009) for the definitions of these response rates. To check if the response rate had any impact on the representativeness of the sample, we compared our data with the 2006 General Social Survey on several sociodemographic and religious variables. The two datasets were similar in most variables.

${ }^{8}$ This is comparable to the retention rate in the 2008-2009 National Election Study panel, which re-interviewed 63\% of the original respondents 10 months later (DeBell et al. 2009). It is, however, significantly lower than the reinterview rate of the GSS panel, which successfully re-interviewed $76.8 \%$ of the original respondents. Since almost $40 \%$ of the original respondents did not participate in the second wave, attrition bias could be a serious concern, especially if religiosity had any impact on the decision to participate in the second survey. To address this concern, we examined whether attrition was significantly related to religiosity, especially to no religious preference in 2006. In bivariate analysis, the respondents who claimed no religious preference were indeed less likely to participate in the second wave. Religious service attendance in 2006 also predicted panel attrition. But these relationships are mostly due to the high rate of attrition among younger, single, and male respondents. In addition, the panel sample under-represents ethnic minorities and the people with higher education. In short, the panel sample, when not corrected by the sampling weight, may not be considered as a nationally representative sample of Americans.

${ }^{9}$ Brinkerhoff and Mackie (1993) advocate a religious careers approach to understanding apostasy, in which there are four potential career paths; apostates, switchers, converts, and stalwarts. Stalwarts Apostates are those who were raised in a religious tradition but now report not having one. Switchers are those who were raised in a different tradition than the one they report now. Converts are those who started out as nones but have since developed a religious preference. Finally, stalwarts are those who report consistent religious preferences from childhood to adulthood. Though our aim is to explain the instability of religious preferences, it must be noted that a majority of Americans can be considered stable stalwarts.

${ }^{10}$ These are unweighted percentages.

${ }^{11}$ These are unweighted percentages. When the survey weight was applied to correct the biases due to panel attrition, $11.5 \%$ of the panel respondents were stable nones and $10.7 \%$ were liminal nones.

${ }^{12}$ The percentage of religious none in the 1992-1996 NES is about 12 to 13\%, which is slightly higher than the 9.5\% in the 1994 GSS or $12 \%$ in the 1996 GSS.

${ }^{13}$ As the appendix B shows, the GSS 2006-2008 panel is remarkably similar to the FM panel with respect to the stability of religious preference, not only for nones, but also for other religions. For example, both in the FM and the GSS, 91\% of the Catholic respondents in the first wave chose Catholic as their religious preferences in the second wave.

${ }^{14}$ For the change in religious attendance in past five years, we present the results from the 2007 survey.

${ }^{15}$ About a third of them said they were "absolutely sure" that God exists, and another $15 \%$ said that they were "somewhat sure."

${ }^{16}$ These findings on the two 'other' categories should be interpreted with a caution as they are based on a relatively small number of observations. Among the panel respondents, only 64 respondents ( $3.4 \%$ of the total panel respondents) belonged to the 'other non-Christian' traditions in at least one of the two waves. A somewhat larger number of respondents (5\%) belonged to the 'other Protestant/Christian' traditions.

${ }^{17}$ We found a similar pattern in the GSS panel as well.

${ }^{18}$ This is the case even in the year in which the liminal reported something other than 'nothing in particular.' 
References

Alwin, Duane F. 2007. Margins of Error: A Study of Reliability in Survey Measurement. Hoboken, N.J.: Wiley-Interscience.

Baker, Joseph O. and Buster G. Smith. 2008. "The Nones: Social Characteristics of the Religiously Unaffiliated." Social Forces 87:1251-1263.

Bartkowski, John P. 2000. "Breaking Walls, Raising Fences: Masculinity, Intimacy, and Accountability among the Promise Keepers." Sociology of Religion 61:33-53.

Bellah, Robert Neelly. 1985. Habits of the Heart: Individualism and Commitment in American Life. Berkeley: University of California Press.

Bobby, C. Alexander. 1991. "Correcting Misinterpretations of Turner's Theory: An AfricanAmerican Pentecostal Illustration." Journal for the Scientific Study of Religion 30:26-44.

Brinkerhoff, Merlin B. and Marlene M. Mackie. 1993. "Casting off the Bonds of Organized Religion: A Religious-Careers Approach to the Study of Apostasy." Review of Religious Research 34:235-258.

Brody, Charles J. 1986. "Things Are Rarely Black and White: Admitting Gray Into the Converse Model of Attitude Stability." The American Journal of Sociology 92:657-677.

Bruce, Steve. 2002. God is Dead: Secularization in the West. Malden, MA: Blackwell Pub.

Chaves, Mark. 2010. "Rain Dances in the Dry Season: Overcoming the Religious Congruence Fallacy.” Journal for the Scientific Study of Religion 49: 1-14.

Cimino, Richard P. and Don Lattin. 1998. Shopping for Faith: American Religion in the New Millennium. San Francisco: Jossey-Bass.

Davie, Grace. 1994. Religion in Britain since 1945: Believing without Belonging. Oxford ; Cambridge, Mass.: Blackwell.

Dougherty, Kevin D., Byron R. Johnson, and Edward C. Polson. 2007. "Recovering the Lost: Remeasuring U.S. Religious Affiliation." Journal for the Scientific Study of Religion 46:483-499.

Fishman, Robert G. 1980. "Transmigration, Liminality, and Spiritualist Healing." Journal of Religion and Health 19:217-225.

Fuller, Robert C. 2001. Spiritual, But Not Religious: Understanding Unchurched America. Oxford New York: Oxford University Press.

Glenn, Norval D. 1987. "The Trend in "No Religion" Respondents to U.S. National Surverys, Late 1950s to Early 1980s." Public Opin Q 51:293-314.

Green, Donald P., Bradley Palmquist, and Eric Schickler. 2002. Partisan Hearts and Minds: Political Parties and the Social Identities of Voters. New Haven, Conn. ; London: Yale University Press.

Greer, Bruce A. and Wade Clark Roof. 1992. "'Desperately Seeking Sheila": Locating Religious Privatism in American Society." Journal for the Scientific Study of Religion 31:346-352.

Hadaway, C. Kirk and Wade Clark Roof. 1979. "Those Who Stay Religious "Nones" and Those Who Don't: A Research Note." Journal for the Scientific Study of Religion 18:194-200.

Hoge, Dean R., Benton Johnson, and Donald A. Luidens. 1994. Vanishing Boundaries: The Religion of Mainline Protestant Baby Boomers. Louisville, Ky.: Westminster/John Knox Press.

Hout, Michael and Claude S. Fischer. 2002. "Why More Americans Have No Religious Preference: Politics and Generations." American Sociological Review 67:165-190. 
Hutch, Richard A. 1980. "The Personal Ritual of Glossolalia." Journal for the Scientific Study of Religion 19:255-266.

Kosmin, Barry A. and Ariela Keysar. 2009. "American Nones: The Profile of the No Religion Population: A Report Based on the American Religious Identification Survey 2008." Trinity College, Hartford, CT.

Markus, Hazel and Ziva Kunda. 1986. "Stability and malleability of the self-concept." Journal of Personality and Social Psychology 51:858-866.

Marwell, Gerald and N. J. Demerath Iii. 2003. "'Secularization" by Any Other Name." American Sociological Review 68:314-316.

Meacham, Jon 2009. "The End of Christian America." Newsweek, April 13.

Ragin, Charles C. 2000. Fuzzy-Set Social Science. Chicago: University of Chicago Press.

Roof, Wade Clark. 1993. A Generation of Seekers: The Spiritual Journeys of the Baby Boom Generation. [San Francisco]: HarperSanFrancisco.

- 1999. Spiritual Marketplace: Baby Boomers and the Remaking of American Religion. Princeton, N.J . Princeton University Press.

Roof, Wade Clark and William McKinney. 1987. American Mainline Religion: Its Changing Shape and Future. New Brunswick, [N.J.]: Rutgers University Press.

Sheldon, Stryker and Richard T. Serpe. 1994. "Identity Salience and Psychological Centrality: Equivalent, Overlapping, or Complementary Concepts?" Social Psychology Quarterly 57:16-35.

Sherkat, Darren E. 1991. "Leaving the faith: Testing theories of religious switching using survival models." Social Science Research 20:171-187.

Sherkat, Darren E. and John Wilson. 1995. "Preferences, Constraints, and Choices in Religious Markets: An Examination of Religious Switching and Apostasy." Social Forces 73:9931026.

Smith, Christian and David Sikkink. 2003. "Social Predictors of Retention in and Switching from the Religious Faith of Family of Origin: Another Look Using Religious Tradition SelfIdentification." Review of Religious Research 45:188-206.

Smith, Tom and Seokho Kim. 2005. "The Vanishing Protestant Majority." Journal for the Scientific Study of Religion 44:211-223.

Stark, Rodney. 2008. What Americans Really Believe: New Findings from the Baylor Surveys of Religion. Waco, Tex.: Baylor University Press.

Steensland, Brian, Jerry Z. Park, Mark D. Regnerus, Lynn D. Robinson, W. Bradford Wilcox, and Robert D. Woodberry. 2000. "The Measure of American Religion: Toward Improving the State of the Art." Social Forces 79:291-318.

Tamney, Joseph B., Shawn Powell, and Stephen Johnson. 1989. "Innovation Theory and Religious Nones." Journal for the Scientific Study of Religion 28:216-229.

The American Association for Public Opinion Research. 2009. Standard Definitions: Final Dispositions of Case Codes and Outcome Rates for Surveys. Retrieved April 19, 2010, from http://www.aapor.org/AM/Template.cfm?Section=Standard_Definitions1\&Template=/C M/ContentDisplay.cfm\&ContentID=1814

The National Opinion Research Center. 2009. “Appendix A: Sampling Design and Weighting.” Retrieved April 19, 2010 from http://publicdata.norc.org:41000/gss/Documents/Codebook/A.pdf 
Turner, Victor Witter. 1969. The Ritual Process: Structure and Anti-Structure. Chicago,: Aldine Pub. Co.

Turner, Victor Witter and Edith L. B. Turner. 1978. Image and Pilgrimage in Christian Culture: Anthropological Perspectives. New York: Columbia University Press.

Vernon, Glenn M. 1968. "The Religious "Nones": A Neglected Category." Journal for the Scientific Study of Religion 7:219-229.

Voas, David. 2009. "The Rise and Fall of Fuzzy Fidelity in Europe." Eur Sociol Rev 25:155-168.

Wilson, John and Darren E. Sherkat. 1994. "Returning to the Fold." Journal for the Scientific Study of Religion 33:148-161.

Wuthnow, Robert. 2007. After the Baby Boomers: How Twenty- and Thirty-Somethings are Shaping the Future of American Religion. Princeton: Princeton University Press. 


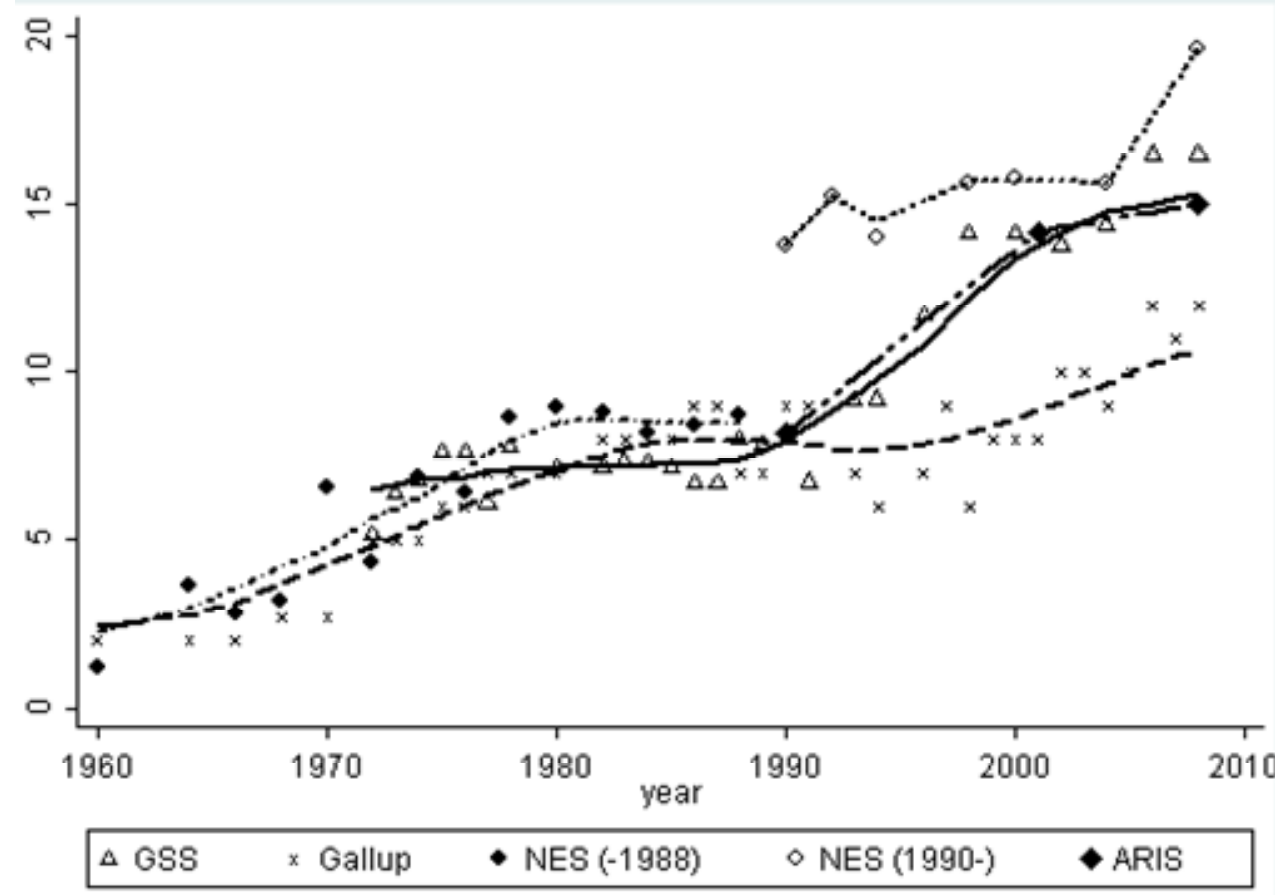

Figure 1 Percentage of religious nones in four national surveys 


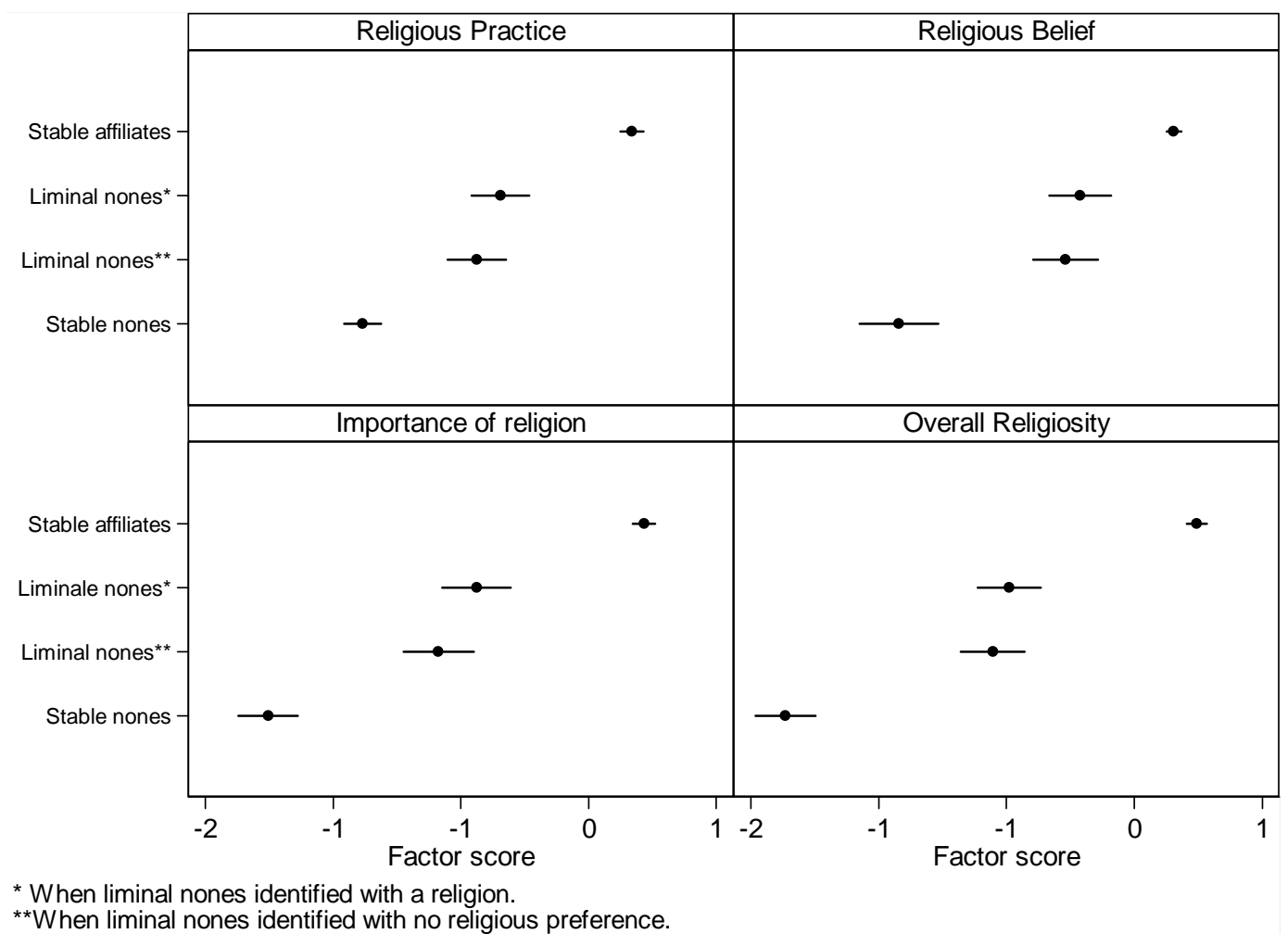

Figure 2 Comparing religiosity: stable affiliates, stable nones, and liminal nones 


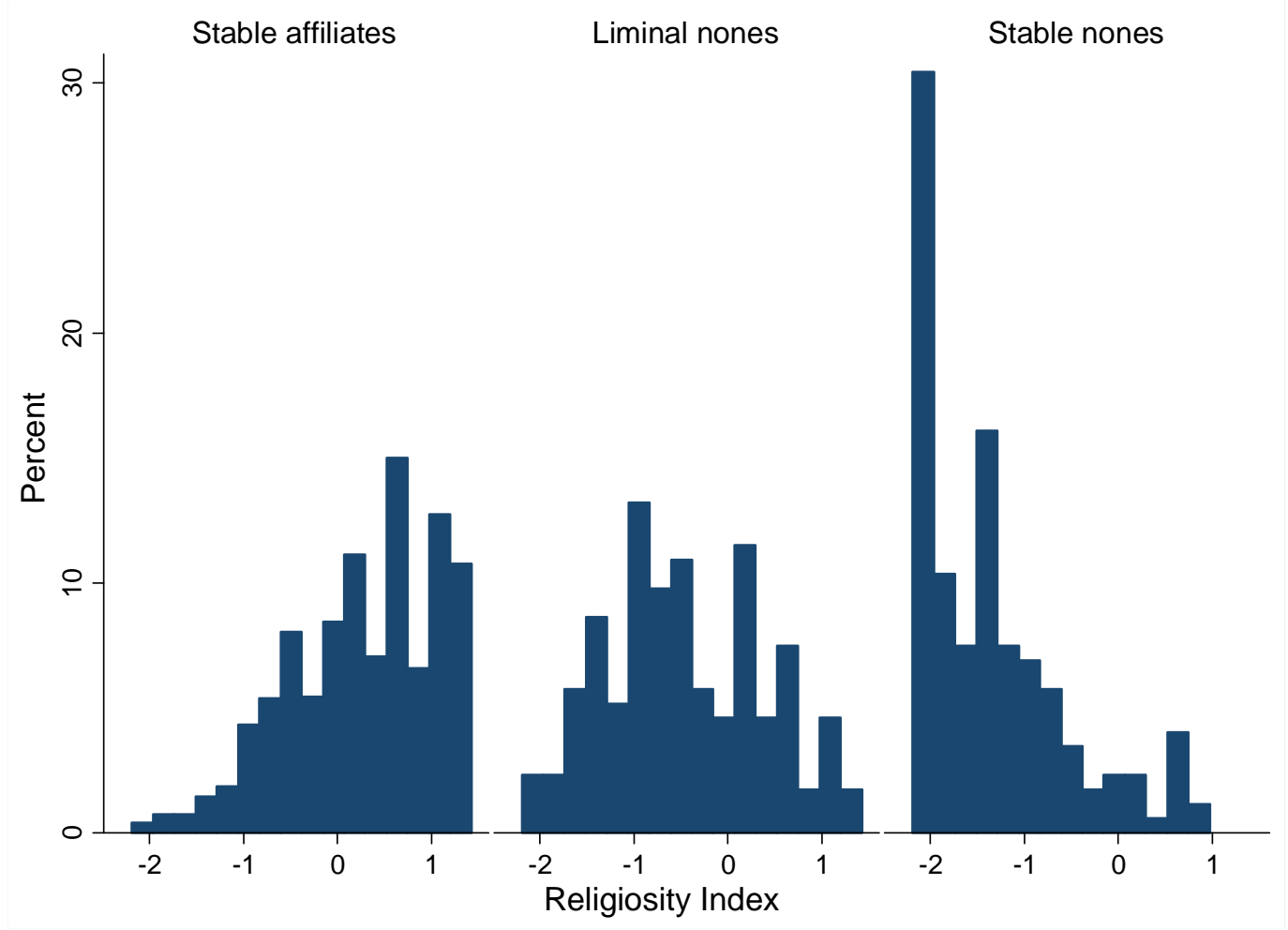

Figure 3 Distribution of religiosity index in stable affiliates, liminal nones, and stable nones 


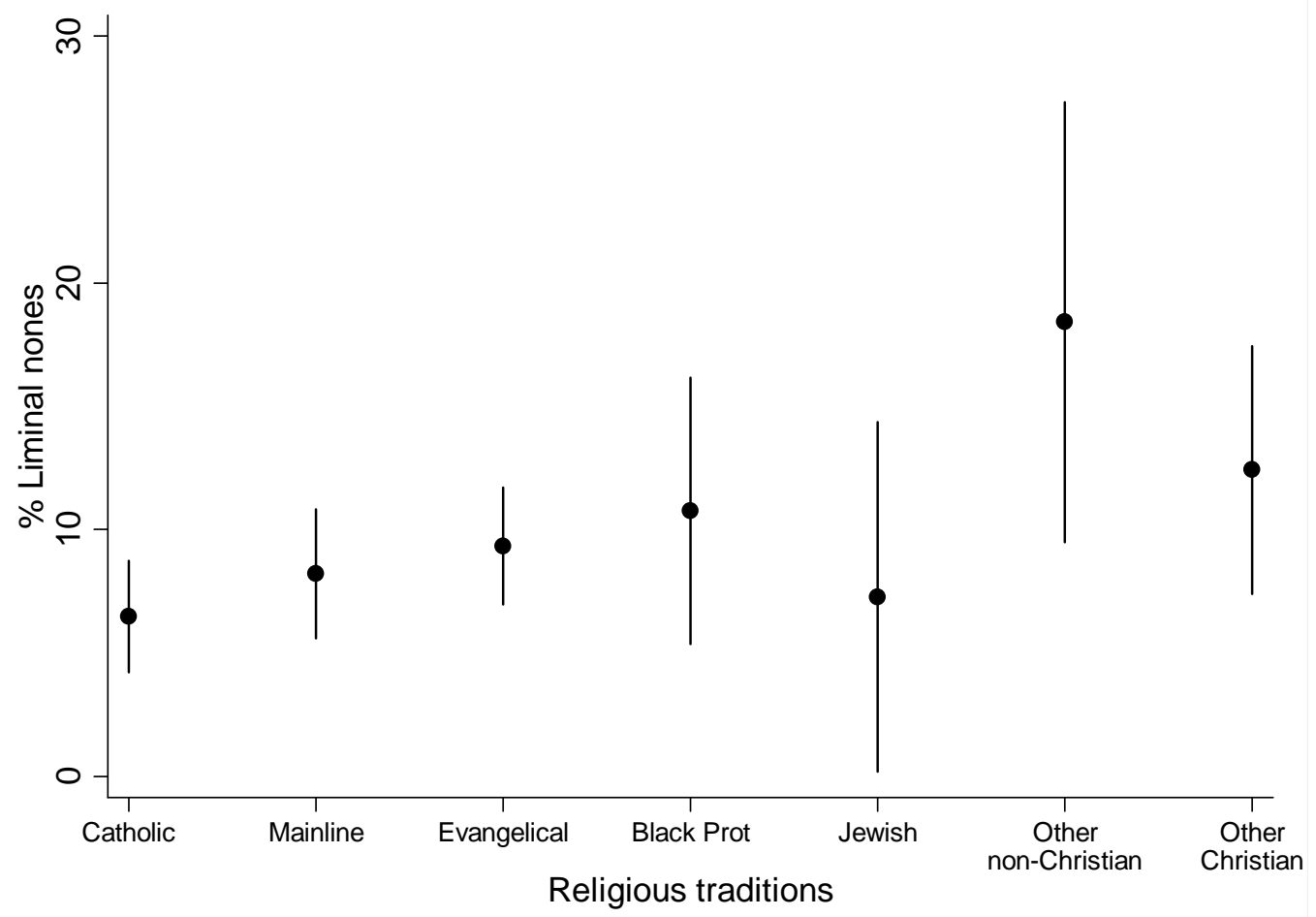

Figure 4 Percentage of liminal nones in various religious traditions 
Table 1 Religious preference in the Faith Matters survey: 2006 and 2007

\begin{tabular}{|c|c|c|c|c|c|c|c|c|}
\hline \multirow[b]{2}{*}{$\begin{array}{l}\text { Religious preference } \\
\text { in } 2006\end{array}$} & \multicolumn{8}{|c|}{ Religious preference in 2007} \\
\hline & & Protstant & Catholic & $\begin{array}{l}\text { Another } \\
\text { type of } \\
\text { Christian }\end{array}$ & Jewish & $\begin{array}{l}\text { Some other } \\
\text { religion }\end{array}$ & $\begin{array}{l}\text { Nothing in } \\
\text { particular }\end{array}$ & Total \\
\hline \multirow[t]{3}{*}{ Protestant } & $\mathrm{N}$ & 593 & 3 & 42 & 0 & 29 & 23 & 690 \\
\hline & Row \% & 85.9 & 0.4 & 6.1 & 0.0 & 4.2 & 3.3 & 100.0 \\
\hline & Col \% & 80.8 & 0.7 & 16.5 & 0.0 & 20.6 & 8.2 & 36.6 \\
\hline \multirow[t]{3}{*}{ Catholic } & $\mathrm{N}$ & 6 & 406 & 5 & 1 & 4 & 20 & 442 \\
\hline & Row \% & 1.4 & 91.9 & 1.1 & 0.2 & 0.9 & 4.5 & 100.0 \\
\hline & Col \% & 0.8 & 95.1 & 2.0 & 2.0 & 2.8 & 7.2 & 23.4 \\
\hline \multirow[t]{3}{*}{ Another type of Christian } & $\mathrm{N}$ & 65 & 5 & 152 & 2 & 39 & 27 & 290 \\
\hline & Row \% & 22.4 & 1.7 & 52.4 & 0.7 & 13.5 & 9.3 & 100.0 \\
\hline & Col \% & 8.9 & 1.2 & 59.6 & 3.9 & 27.7 & 9.7 & 15.4 \\
\hline \multirow[t]{3}{*}{ Jewish } & $\mathrm{N}$ & 0 & 0 & 0 & 43 & 1 & 3 & 47 \\
\hline & Row \% & 0.0 & 0.0 & 0.0 & 91.5 & 2.1 & 6.4 & 100.0 \\
\hline & Col \% & 0.0 & 0.0 & 0.0 & 84.3 & 0.7 & 1.1 & 2.5 \\
\hline \multirow[t]{3}{*}{ Some other religion } & $\mathrm{N}$ & 37 & 3 & 34 & 4 & 56 & 26 & 160 \\
\hline & Row \% & 23.1 & 1.9 & 21.3 & 2.5 & 35.0 & 16.3 & 100.0 \\
\hline & Col \% & 5.0 & 0.7 & 13.3 & 7.8 & 39.7 & 9.3 & 8.5 \\
\hline \multirow[t]{3}{*}{ Nothing in particular } & $\mathrm{N}$ & 33 & 10 & 22 & 1 & 12 & 180 & 258 \\
\hline & Row \% & 12.8 & 3.9 & 8.5 & 0.4 & 4.7 & 69.8 & 100.0 \\
\hline & Col \% & 4.5 & 2.3 & 8.6 & 2.0 & 8.5 & 64.5 & 13.7 \\
\hline \multirow[t]{3}{*}{ Total } & $\mathrm{N}$ & 734 & 427 & 255 & 51 & 141 & 279 & 1,887 \\
\hline & Row \% & 38.9 & 22.6 & 13.5 & 2.7 & 7.5 & 14.8 & 100.0 \\
\hline & Col \% & 100.0 & 100.0 & 100.0 & 100.0 & 100.0 & 100.0 & 100.0 \\
\hline
\end{tabular}


Table 2 Stability of religious preference in FM, ANES and GSS (\%)

\begin{tabular}{|c|c|c|c|c|}
\hline \multicolumn{2}{|c|}{ Religious preference } & \multirow{2}{*}{$\begin{array}{c}\text { Faith Matters } \\
(2006-2007)\end{array}$} & \multirow{2}{*}{$\begin{array}{c}\text { ANES } \\
(1992-1996) \\
\end{array}$} & \multirow{2}{*}{$\begin{array}{c}\text { GSS } \\
(2006-2008) \\
\end{array}$} \\
\hline Wave 1 & Wave 2 & & & \\
\hline Religion & Religion & 81.0 & 82.2 & 78.8 \\
\hline No Religion & No religion & 9.6 & 8.2 & 10.8 \\
\hline No Religion & Religion & 4.2 & 5.6 & 4.9 \\
\hline Religion & No religion & 5.2 & 4.1 & 5.5 \\
\hline
\end{tabular}


Table 3 Self-reported religious changes in past year (\%)

\begin{tabular}{|c|c|c|c|c|}
\hline Religious preference & \multicolumn{4}{|c|}{ Change in religious belief or practice in past year } \\
\hline 2007 & No change & $\begin{array}{l}\text { Increased } \\
\text { religiosity }\end{array}$ & $\begin{array}{l}\text { Decreased } \\
\text { religiosity }\end{array}$ & $\begin{array}{c}\text { Other } \\
\text { change }\end{array}$ \\
\hline Religion & 90.4 & 4.4 & 2.3 & 2.9 \\
\hline (Adjusted Residual) & $(-0.1)$ & (1.4) & (0.4) & $(-1.8)$ \\
\hline No religion No religion & 92.3 & 2.2 & 1.7 & 3.9 \\
\hline (Adjusted Residual) & (0.9) & $(-1.4)$ & $(-0.5)$ & (0.5) \\
\hline No religion Religion & 84.8 & 7.6 & 2.5 & 5.1 \\
\hline (Adjusted Residual) & $(-1.7)$ & (1.6) & (0.2) & (0.9) \\
\hline No religion & 91.9 & 0.0 & 2.0 & 6.1 \\
\hline (Adjusted Residual) & $(0.5)$ & $(-2.1)$ & $(-0.1)$ & (1.6) \\
\hline Total & 90.4 & 4.1 & 2.2 & 3.2 \\
\hline
\end{tabular}

Pearson chi-2 (d.f. $=9)=13.2(p>1.00)$

Table 4 Self-reported changes in religious service attendance in past five years (\%)

\begin{tabular}{|c|c|c|c|c|}
\hline \multicolumn{2}{|c|}{ Religious preference } & \multicolumn{3}{|c|}{$\begin{array}{l}\text { Change in religious service attendance } \\
\text { in last five years }\end{array}$} \\
\hline 2006 & 2007 & Decreased & About the same & Increased \\
\hline Religion & Religion & 19.0 & 64.7 & 16.4 \\
\hline \multicolumn{2}{|c|}{ (Adjusted Residual) } & $(0.5)$ & $(-2.1)$ & $(2.2)$ \\
\hline No religion & No religion & 14.4 & 79.6 & 6.1 \\
\hline \multicolumn{2}{|c|}{ (Adjusted Residual) } & $(-2.9)$ & (4.9) & $(-3.2)$ \\
\hline No religion & Religion & 19.0 & 58.2 & 22.8 \\
\hline \multicolumn{2}{|c|}{ (Adjusted Residual) } & (1.1) & $(-1.2)$ & $(0.4)$ \\
\hline Religion & No religion & 26.7 & 58.6 & 15.2 \\
\hline \multicolumn{2}{|c|}{ (Adjusted Residual) } & (1.9) & $(-1.6)$ & $(0.0)$ \\
\hline \multicolumn{2}{|c|}{ Total } & 19.6 & 64.2 & 16.1 \\
\hline
\end{tabular}

Pearson chi-2 (d.f. = 6) $=28.6(p<0.001)$ 
Table 5 Changes in religiosity in liminal nones, stable nones, and stable affiliates (\%)

\begin{tabular}{|c|c|c|c|c|c|c|}
\hline \multirow[b]{2}{*}{ Measures of religiosity } & \multicolumn{3}{|c|}{ Liminal Nones } & \multicolumn{2}{|c|}{ Stable affiliates Stable nones } & \multirow[b]{2}{*}{$x^{2}$ test } \\
\hline & $\begin{array}{c}\text { Less religious } \\
\text { when } \mathrm{R} \text { is } \\
\text { none }\end{array}$ & $\begin{array}{c}\text { Same } \\
\text { response }\end{array}$ & $\begin{array}{c}\text { More religious } \\
\text { when } \mathrm{R} \text { is } \\
\text { none }\end{array}$ & $\begin{array}{c}\text { Same } \\
\text { response }\end{array}$ & $\begin{array}{c}\text { Same } \\
\text { response }\end{array}$ & \\
\hline \multicolumn{7}{|l|}{ Importane of religion: } \\
\hline .... in daily life & 20.6 & 66.9 & 12.6 & 66.7 & 72.5 & \\
\hline ...to the sense of who I am & 29.1 & 49.1 & 16.6 & 67.0 & 63.1 & *** \\
\hline ....in making decisions on family & 27.8 & 51.1 & 17.6 & 62.2 & 61.5 & * \\
\hline ...in making decisions on politics & 22.0 & 59.5 & 18.5 & 58.1 & 64.8 & \\
\hline \multicolumn{7}{|l|}{ Religious practice: How often... } \\
\hline ....attend religious service & 36.5 & 42.7 & 20.8 & 53.2 & 61.5 & ** \\
\hline ...pray & 31.3 & 43.2 & 25.6 & 48.8 & 57.5 & * \\
\hline ... read holy scripture & 18.6 & 64.4 & 17.0 & 53.8 & 72.9 & *** \\
\hline ...say grace & 22.1 & 60.5 & 17.4 & 58.7 & 67.7 & \\
\hline \multicolumn{7}{|l|}{ Religious belief: how sure that... } \\
\hline ...you believe in God & 13.1 & 79.6 & 7.4 & 88.9 & 62.2 & $* * *$ \\
\hline ...you believe in afterlife & 29.7 & 46.3 & 24.0 & 69.8 & 54.5 & $* * *$ \\
\hline
\end{tabular}

${ }^{*} p<.05 ;{ }^{* *} p<.01 ;{ }^{* * *} p<.001$ 
Table 6 Multinominal logistic regression of liminality in religious preference (baseline $=$ liminal nones)

\begin{tabular}{|c|c|c|c|c|c|c|c|c|}
\hline & \multicolumn{2}{|c|}{ Model 1} & \multicolumn{2}{|c|}{ Model 2} & \multicolumn{2}{|c|}{ Model 3} & \multicolumn{2}{|c|}{ Model 4} \\
\hline & $\begin{array}{c}\text { stable } \\
\text { affiliates }\end{array}$ & $\begin{array}{l}\text { stable } \\
\text { nones }\end{array}$ & $\begin{array}{c}\text { stable } \\
\text { affiliates }\end{array}$ & $\begin{array}{l}\text { stable } \\
\text { nones }\end{array}$ & $\begin{array}{c}\text { stable } \\
\text { affiliates }\end{array}$ & $\begin{array}{l}\text { stable } \\
\text { nones }\end{array}$ & $\begin{array}{c}\text { stable } \\
\text { affiliates }\end{array}$ & $\begin{array}{l}\text { stable } \\
\text { nones }\end{array}$ \\
\hline \multicolumn{9}{|l|}{ Demographic and social backgrounds } \\
\hline R's age & $\begin{array}{l}0.019 * * \\
(0.007)\end{array}$ & $\begin{array}{c}-0.012 \\
(0.009)\end{array}$ & $\begin{array}{c}0.014+ \\
(0.007)\end{array}$ & $\begin{array}{c}-0.008 \\
(0.009)\end{array}$ & $\begin{array}{l}0.018^{*} \\
(0.008)\end{array}$ & $\begin{array}{c}-0.015+ \\
(0.009)\end{array}$ & $\begin{array}{l}0.016 * \\
(0.007)\end{array}$ & $\begin{array}{l}-0.010 \\
(0.009)\end{array}$ \\
\hline$R$ is male & $\begin{array}{l}-0.266 \\
(0.195)\end{array}$ & $\begin{array}{l}-0.039 \\
(0.252)\end{array}$ & $\begin{array}{l}-0.318 \\
(0.205)\end{array}$ & $\begin{array}{c}0.095 \\
(0.259)\end{array}$ & $\begin{array}{c}-0.417+ \\
(0.217)\end{array}$ & $\begin{array}{c}0.147 \\
(0.267)\end{array}$ & $\begin{array}{l}-0.311 \\
(0.197)\end{array}$ & $\begin{array}{c}0.008 \\
(0.254)\end{array}$ \\
\hline \multicolumn{9}{|l|}{ R's race } \\
\hline $\mathrm{R}$ is white & \multicolumn{8}{|c|}{ (Reference category) } \\
\hline $\mathrm{R}$ is Black & $\begin{array}{l}-0.036 \\
(0.360)\end{array}$ & $\begin{array}{c}-1.288^{*} \\
(0.615)\end{array}$ & $\begin{array}{l}-0.155 \\
(0.374)\end{array}$ & $\begin{array}{c}-1.214+ \\
(0.621)\end{array}$ & $\begin{array}{l}-0.083 \\
(0.404)\end{array}$ & $\begin{array}{c}-1.215+ \\
(0.628)\end{array}$ & $\begin{array}{l}-0.070 \\
(0.366)\end{array}$ & $\begin{array}{r}-1.196+ \\
(0.620)\end{array}$ \\
\hline $\mathrm{R}$ is Asian & $\begin{array}{l}-0.966 \\
(0.694)\end{array}$ & $\begin{array}{l}-0.469 \\
(0.843)\end{array}$ & $\begin{array}{l}-0.420 \\
(0.760)\end{array}$ & $\begin{array}{c}-0.538 \\
(0.863)\end{array}$ & $\begin{array}{l}-0.462 \\
(0.802)\end{array}$ & $\begin{array}{l}-0.687 \\
(0.884)\end{array}$ & $\begin{array}{l}-0.925 \\
(0.715)\end{array}$ & $\begin{array}{l}-0.458 \\
(0.853)\end{array}$ \\
\hline $\mathrm{R}$ is Hispanic & $\begin{array}{l}-0.294 \\
(0.348)\end{array}$ & $\begin{array}{c}-0.942+ \\
(0.515)\end{array}$ & $\begin{array}{c}-0.398 \\
(0.361)\end{array}$ & $\begin{array}{c}-0.926+ \\
(0.520)\end{array}$ & $\begin{array}{c}-0.364 \\
(0.383)\end{array}$ & $\begin{array}{c}-0.964+ \\
(0.540)\end{array}$ & $\begin{array}{l}-0.196 \\
(0.356)\end{array}$ & $\begin{array}{c}-1.046^{*} \\
(0.522)\end{array}$ \\
\hline $\mathrm{R}$ is currently married & $\begin{array}{l}0.483^{*} \\
(0.221)\end{array}$ & $\begin{array}{c}-0.092 \\
(0.286)\end{array}$ & $\begin{array}{l}0.711^{* *} \\
(0.233)\end{array}$ & $\begin{array}{c}-0.318 \\
(0.299)\end{array}$ & $\begin{array}{l}0.643 * * \\
(0.246)\end{array}$ & $\begin{array}{l}-0.325 \\
(0.303)\end{array}$ & $\begin{array}{c}0.351 \\
(0.227)\end{array}$ & $\begin{array}{c}-0.021 \\
(0.294)\end{array}$ \\
\hline R lives with young children & $\begin{array}{c}0.093 \\
(0.231)\end{array}$ & $\begin{array}{c}-0.096 \\
(0.297)\end{array}$ & $\begin{array}{c}0.145 \\
(0.238)\end{array}$ & $\begin{array}{l}-0.099 \\
(0.298)\end{array}$ & $\begin{array}{c}0.342 \\
(0.258)\end{array}$ & $\begin{array}{c}-0.361 \\
(0.320)\end{array}$ & $\begin{array}{c}0.027 \\
(0.233)\end{array}$ & $\begin{array}{c}-0.026 \\
(0.298)\end{array}$ \\
\hline Education (years) & $\begin{array}{c}-0.021 \\
(0.045)\end{array}$ & $\begin{array}{c}0.028 \\
(0.059)\end{array}$ & $\begin{array}{l}-0.040 \\
(0.045)\end{array}$ & $\begin{array}{c}0.036 \\
(0.058)\end{array}$ & $\begin{array}{l}-0.041 \\
(0.048)\end{array}$ & $\begin{array}{c}0.048 \\
(0.061)\end{array}$ & $\begin{array}{c}0.020 \\
(0.046)\end{array}$ & $\begin{array}{l}-0.020 \\
(0.059)\end{array}$ \\
\hline Income $(\$ 1,000)$ & $\begin{array}{l}-0.004 \\
(0.003)\end{array}$ & $\begin{array}{l}-0.002 \\
(0.004)\end{array}$ & $\begin{array}{l}-0.003 \\
(0.003)\end{array}$ & $\begin{array}{l}-0.002 \\
(0.004)\end{array}$ & $\begin{array}{l}-0.001 \\
(0.003)\end{array}$ & $\begin{array}{l}-0.004 \\
(0.004)\end{array}$ & $\begin{array}{l}-0.003 \\
(0.003)\end{array}$ & $\begin{array}{l}-0.001 \\
(0.004)\end{array}$ \\
\hline \multicolumn{9}{|l|}{ Religious backgrounds } \\
\hline $\begin{array}{c}\text { Religious senvice attendance } \\
\text { as a child (days per year) }\end{array}$ & & & $\begin{array}{l}0.011^{*} \\
(0.005)\end{array}$ & $\begin{array}{l}-0.003 \\
(0.006)\end{array}$ & $\begin{array}{l}0.012 * \\
(0.005)\end{array}$ & $\begin{array}{l}-0.002 \\
(0.006)\end{array}$ & & \\
\hline Parents have no religion & & & $\begin{array}{c}-1.481^{* * *} \\
(0.319)\end{array}$ & $\begin{array}{l}-0.073 \\
(0.353)\end{array}$ & $\begin{array}{l}-0.898^{*} \\
(0.375)\end{array}$ & $\begin{array}{l}-0.351 \\
(0.365)\end{array}$ & & \\
\hline Spouse has no religion & & & $\begin{array}{c}-1.790 * * * \\
(0.279)\end{array}$ & $\begin{array}{l}0.726 * \\
(0.306)\end{array}$ & $\begin{array}{c}-1.365^{* * *} \\
(0.312)\end{array}$ & $\begin{array}{c}0.518 \\
(0.321)\end{array}$ & & \\
\hline (First) child has no religion & & & & & $\begin{array}{c}-4.565^{* * *} \\
(0.555)\end{array}$ & $\begin{array}{c}1.019 * * * \\
(0.300)\end{array}$ & & \\
\hline \multicolumn{9}{|l|}{ Political and social attitudes } \\
\hline $\begin{array}{l}\text { R's view on abortion } \\
\text { (high number = prochoice) }\end{array}$ & & & & & & & $\begin{array}{l}-0.190+ \\
(0.110)\end{array}$ & $\begin{array}{c}0.154 \\
(0.155)\end{array}$ \\
\hline $\begin{array}{l}\text { R's view on gay marriage } \\
\text { (high number = pro-gaymarriage) }\end{array}$ & & & & & & & $\begin{array}{l}-0.235 \\
(0.144)\end{array}$ & $\begin{array}{c}0.154 \\
(0.195)\end{array}$ \\
\hline $\begin{array}{l}\text { Political orientation } \\
\text { (high number = liberal) }\end{array}$ & & & & & & & $\begin{array}{c}-0.320^{* *} \\
(0.098)\end{array}$ & $\begin{array}{l}0.303^{*} \\
(0.131)\end{array}$ \\
\hline Constant & $\begin{array}{l}1.747^{*} \\
(0.731) \\
\end{array}$ & $\begin{array}{c}0.676 \\
(0.941)\end{array}$ & $\begin{array}{l}2.019 * * \\
(0.753)\end{array}$ & $\begin{array}{c}0.349 \\
(0.931)\end{array}$ & $\begin{array}{l}1.940 * \\
(0.798)\end{array}$ & $\begin{array}{c}0.369 \\
(0.980) \\
\end{array}$ & $\begin{array}{c}3.056^{* * *} \\
(0.782)\end{array}$ & $\begin{array}{l}-0.589 \\
(1.019)\end{array}$ \\
\hline Observations & \multicolumn{2}{|c|}{1510} & \multicolumn{2}{|c|}{1510} & \multicolumn{2}{|c|}{1510} & \multicolumn{2}{|c|}{1510} \\
\hline Pseudo R-squared & \multicolumn{2}{|c|}{0.038} & \multicolumn{2}{|c|}{0.144} & \multicolumn{2}{|c|}{0.295} & \multicolumn{2}{|c|}{0.119} \\
\hline
\end{tabular}

${ }^{+} \mathrm{p}<.10 ;{ }^{*} \mathrm{p}<.05 ;{ }^{* *} \mathrm{p}<.01 ;{ }^{* * *} \mathrm{p}<.001$ (two-tailed test) 
Appendix A. Religious preference in the American National Election Studies (NES)

The 1992-1996 NES comprises three waves of surveys, which were conducted in 1992, 1994, and 1996 respectively. The panel respondents $(\mathrm{N}=1,316)$ were asked about their religious preferences twice, either in 1992 and 1996 or in 1994 and 1996 (Sapiro et al. 1998). In each survey, the respondents were first asked whether they "ever attend religious services, apart from occasional weddings, baptisms or funerals.” For the respondents who said they did not attend religious services, the survey asked whether they thought of themselves "as part of a particular church or denomination,” regardless of religious service attendance. Only the respondents who said no to both of these questions were coded as "none." This procedure is different from the one used in the Faith Matters survey or the GSS in a couple of ways. First, it considers church attendance as a necessary condition for being a religious none. Second, the preference is also defined as a sense of belonging to a "particular church or denomination" rather than the identification with general religious groups or traditions.

Because the intervals between the first and the second interviews vary, we may expect a higher level of uncertainty among the respondents who were re-interviewed four years after the initial interviews than among those who were re-interviewed two years later. In fact, the percentage of liminal nones was higher in the former group than in the latter, but only by a small margin; about $10.2 \%$ of the former and $9.2 \%$ of the latter were liminal nones.

We also examined whether the liminal nones reported a higher level of religiosity when they reported no religious preference than when they were identified as something else. To measure religiosity, we used the question on the importance of religion in the respondent's life. Regardless of expressed religious preference, the liminal nones reported a similar level of religiosity in both waves, which locates them between the stable affiliates and the stable nones. 
Appendix B. Religious preference in the 2006-2008 General Social Survey Panel

\begin{tabular}{|c|c|c|c|c|c|c|c|c|}
\hline & Protestant & Catholic & Jewish & No eligion & Others & $\begin{array}{c}\text { Other } \\
\text { non-Christian } \\
\text { religions }^{\mathrm{a}}\end{array}$ & $\begin{array}{c}\text { Other } \\
\text { Christian } \\
\text { religions }^{\mathrm{b}}\end{array}$ & Total \\
\hline \multirow{3}{*}{ Protestant } & 707 & 13 & 1 & 49 & 2 & 5 & 34 & 811 \\
\hline & 87.2 & 1.6 & 0.1 & 6.0 & 0.3 & 0.6 & 4.2 & 100.0 \\
\hline & 90.6 & 3.5 & 4.4 & 19.7 & 16.7 & 13.5 & 59.7 & 53.1 \\
\hline \multirow[t]{3}{*}{ Catholic } & 11 & 340 & 0 & 15 & 2 & 0 & 2 & 370 \\
\hline & 3.0 & 91.9 & 0.0 & 4.1 & 0.5 & 0.0 & 0.5 & 100.0 \\
\hline & 1.4 & 91.9 & 0.0 & 6.0 & 16.7 & 0.0 & 3.5 & 24.2 \\
\hline \multirow[t]{3}{*}{ Jewish } & 1 & 1 & 22 & 1 & 0 & 0 & 0 & 25 \\
\hline & 4.0 & 4.0 & 88.0 & 4.0 & 0.0 & 0.0 & 0.0 & 100.0 \\
\hline & 0.1 & 0.3 & 95.7 & 0.4 & 0.0 & 0.0 & 0.0 & 1.6 \\
\hline \multirow[t]{3}{*}{ No Religion } & 41 & 13 & 0 & 165 & 4 & 10 & 7 & 240 \\
\hline & 17.1 & 5.4 & 0.0 & 68.8 & 1.7 & 4.2 & 2.9 & 100.0 \\
\hline & 5.3 & 3.5 & 0.0 & 66.3 & 33.3 & 27.0 & 12.3 & 15.7 \\
\hline \multirow[t]{3}{*}{ Others } & 2 & 0 & 0 & 9 & 3 & 3 & 0 & 17 \\
\hline & 11.8 & 0.0 & 0.0 & 52.9 & 17.7 & 17.7 & 0.0 & 100.0 \\
\hline & 0.3 & 0.0 & 0.0 & 3.6 & 25.0 & 8.1 & 0.0 & 1.1 \\
\hline \multirow[t]{3}{*}{ Other non-Christian religions ${ }^{a}$} & 2 & 1 & 0 & 3 & 1 & 18 & 0 & 25 \\
\hline & 8.0 & 4.0 & 0.0 & 12.0 & 4.0 & 72.0 & 0.0 & 100.0 \\
\hline & 0.3 & 0.3 & 0.0 & 1.2 & 8.3 & 48.7 & 0.0 & 1.6 \\
\hline \multirow[t]{3}{*}{ Other Christian religions ${ }^{\mathrm{b}}$} & 16 & 2 & 0 & 7 & 0 & 1 & 14 & 40 \\
\hline & 40.0 & 5.0 & 0.0 & 17.5 & 0.0 & 2.5 & 35.0 & 100.0 \\
\hline & 2.1 & 0.5 & 0.0 & 2.8 & 0.0 & 2.7 & 24.6 & 2.6 \\
\hline \multirow[t]{3}{*}{ Total } & 780 & 370 & 23 & 249 & 12 & 37 & 57 & 1,528 \\
\hline & 51.1 & 24.2 & 1.5 & 16.3 & 0.8 & 2.4 & 3.7 & 100.0 \\
\hline & 100.0 & 100.0 & 100.0 & 100.0 & 100.0 & 100.0 & 100.0 & 100.0 \\
\hline
\end{tabular}

a. This category includes Buddhism, Hinduism, other Eastern religions, Moslem/Islam, and Native American.

b. This category includes orthodox-Christian, Christian, and Inter-nondenominational. 
Appendix C. Stable none and liminal none within each age group: FM and GSS panel ${ }^{a}$

\begin{tabular}{llrr|rr}
\hline & \multicolumn{3}{c|}{ FM panel } & \multicolumn{2}{c}{ GSS 2006-2008 panel } \\
& & Stable none & Liminal none & Stable none & Liminal none \\
\hline $18-29$ & $\mathrm{~N}$ & 39 & 17 & 52 & 37 \\
& $\%$ & 22.0 & 9.6 & 21.1 & 15.0 \\
$30-39$ & $\mathrm{~N}$ & 25 & 31 & 34 & 42 \\
& $\%$ & 10.7 & 13.3 & 12.8 & 15.8 \\
$40-49$ & $\mathrm{~N}$ & 38 & 46 & 24 & 35 \\
& $\%$ & 9.8 & 11.8 & 8.5 & 12.4 \\
$50-59$ & $\mathrm{~N}$ & 44 & 41 & 28 & 24 \\
& $\%$ & 10.5 & 9.8 & 10.6 & 9.1 \\
$60-69$ & $\mathrm{~N}$ & 23 & 28 & 17 & 13 \\
& $\%$ & 6.7 & 8.1 & 9.3 & 7.1 \\
$70+$ & $\mathrm{N}$ & 12 & 12 & 10 & 8 \\
& $\%$ & 3.9 & 3.9 & 5.5 & 4.4 \\
\hline Total & $\mathrm{N}$ & 181 & 175 & 165 & 159 \\
& $\%$ & 9.7 & 9.3 & 11.6 & 11.2 \\
\hline
\end{tabular}

${ }^{a}$ Unweighted row percentages in each age group 